\title{
A thermodynamic treatment of chemical reactions in orthopyroxene
}

\author{
YASUTAMI OKA \\ Department of Geology and Mineralogy, Hokkaido University, \\ Sapporo, 060 Japan
}

(Received March 22, 1976; accepted in revised form September 16, 1976)

\begin{abstract}
Mixing of $\mathrm{Fe}$ and $\mathrm{Mg}$ in orthopyroxene crystalline solution can be represented by a multicomponent regular solution model when the molecules $\left(\mathrm{Mg}^{\mathrm{M} 1} \mathrm{Mg}^{\mathrm{M} 2} \mathrm{Si}_{2} \mathrm{O}_{6}, \mathrm{Fe}^{\mathrm{M} 1} \mathrm{Fe}^{\mathrm{M} 2} \mathrm{Si}_{2} \mathrm{O}_{6}, \mathrm{Fe}^{\mathrm{M} 1} \mathrm{Mg}^{\mathrm{M} 2} \mathrm{Si}_{2} \mathrm{O}_{6}\right.$ and $\left.\mathrm{Mg}^{\mathrm{M} 1} \mathrm{Fe}^{\mathrm{M}^{2}} \mathrm{Si}_{2} \mathrm{O}_{6}\right)$ are introduced as its components. In this regular solution model, there are three independent interaction parameters $\left(\mathrm{W}^{\mathrm{M} 1}, \mathrm{~W}^{\mathrm{M} 2}\right.$ and $\left.\mathrm{W}^{\mathrm{M} 12}\right)$ which correspond to the cation interactions between M1 and M1 sites, M2 and M2 sites and M1 and M2 sites, respectively. These parameters can not be determined uniquely by site-occupancy measurements only. Some thermodynamic formulations for orthopyroxene are given by using these parameters.
\end{abstract}

\section{INTRODUCTION}

Interaction of $\mathrm{Fe}$ and $\mathrm{Mg}$ in orthopyroxene crystalline solution was discussed by SAXENA and GHose (1971) on the basis of their site-occupancy measurements. In order to explain the observed compositional dependence of the apparent internal partition constant, they assumed that site-occupancy in both M1 and M2 sites of orthopyroxene can be treated as regular solutions. At the same time, they introduced the concept of chemical potential of ions in M1 and M2 sites. This treatment was followed by SAXENA (1973). Since chemical potential can not be defined for ions in silicates (MUELLER et al., 1970), the physical meaning of the thermodynamic parameters in their discussions, however, is not clear. Also, if there are cation interactions between M1 and M2 sites, their treatment becomes no longer valid. Since M1 and M2 sites form the nearest neighbouring cation pairs, the validity of their treatment is questionable (Matsui and Nishizawa, 1975; BANNO, 1974). A more reasonable solution model is needed in order to understand the nature of chemical reactions in orthopyroxene. In this paper, a treatment based on a multicomponent regular solution model is presented.

\section{THERMODYNAMICS}

Let us consider an isolated orthopyroxene whose composition lies in the enstatite-ferrosilite join. As a result of the mixing of $\mathrm{Fe}$ and $\mathrm{Mg}$, the following four kinds of compositional molecules are formed in the crystal (Fig. 1):

$$
\begin{aligned}
\mathrm{En} & =\mathrm{Mg}^{\mathrm{M} 1} \mathrm{Mg}^{\mathrm{M} 2} \mathrm{Si}_{2} \mathrm{O}_{6}, \mathrm{Fs}_{\mathrm{S}}=\mathrm{Fe}^{\mathrm{M} 1} \mathrm{Fe}^{\mathrm{M} 2} \mathrm{Si}_{2} \mathrm{O}_{6} \\
\text { "A" } & =\mathrm{Fe}^{\mathrm{M} 1} \mathrm{Mg}^{\mathrm{M} 2} \mathrm{Si}_{2} \mathrm{O}_{6}, " \mathrm{~B} "=\mathrm{Mg}^{\mathrm{M} 1} \mathrm{Fe}^{\mathrm{M} 2} \mathrm{Si}_{2} \mathrm{O}_{6}
\end{aligned}
$$

Chemical potential for these molecules can be defined as

$$
\mu_{\mathrm{i}}=\frac{\partial \mathrm{G}}{\partial \mathrm{n}_{\mathrm{i}}}
$$

where $n_{i}$ is number of the molecules. Though $\mu_{\mathrm{A}}$ and $\mu_{\mathrm{B}}$ are hypothetical quantities, they have definite physical meaning in the same way as $\mu_{\mathrm{En}}$ and $\mu_{\mathrm{Fs}}$ (BANNO and Matsui, 1967). Using these four kinds of molecules we can write the equilibrium condition as

$$
\begin{gathered}
\delta \mathrm{G}=\mu_{\mathrm{En}} \delta \mathrm{n}_{\mathrm{En}}+\mu_{\mathrm{Fs}} \delta \mathrm{n}_{\mathrm{Fs}}+\mu_{\mathrm{A}} \delta \mathrm{n}_{\mathrm{A}}+\mu_{\mathrm{B}} \delta \mathrm{n}_{\mathrm{B}} \\
=0
\end{gathered}
$$

On the other hand, from the condition of isolation, we have:

$$
\text { 2n } \begin{aligned}
n_{E n}+n_{A}+n_{B}=\text { const. } 2 n_{F s} & +n_{A}+n_{B} \\
= & \text { const. }
\end{aligned}
$$

Using these equations, we obtain the following equilibrium equations:

$$
\mu_{\mathrm{A}}=\mu_{\mathrm{B}}
$$




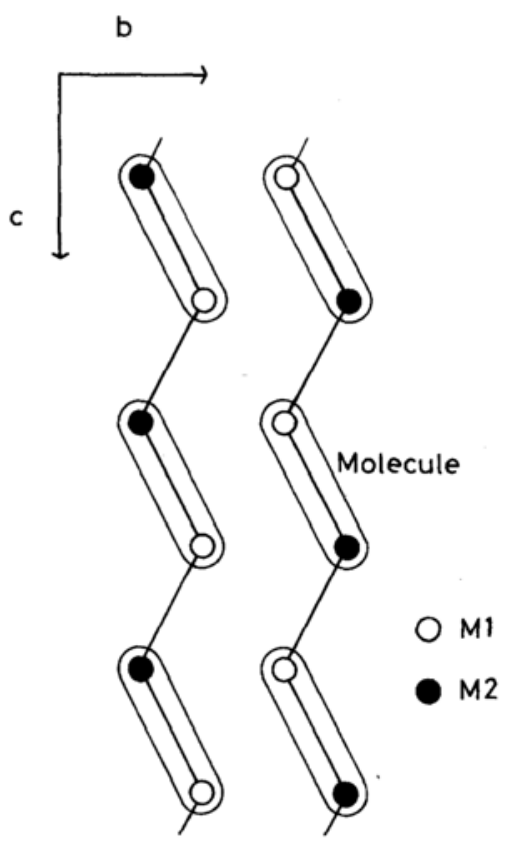

Fig. 1. A shematic representation of the structure of orthopyroxene. Only $M 1$ and $M 2$ sites are represented for simplicity. Since the division of the crystal into molecules is arbitrary, the molecules can be defined in several ways. In this paper, in order to clarify the discussion, the molecules are defined as can be seen. Since the array of M1 and M2 sites forms a twodimensional strip, there are three directions for the nearest neighbouring M1-M2 pair, i.e. one of which is along $b$ axis and the other two are oblique to $b$ axis. When the $M 1-M 2$ interactions are equivalent in all directions, $A-B$ pair is energetically equivalent to En-Fs pair.

$$
2 \mu_{\mathrm{A}}=\mu_{\mathrm{En}}+\mu_{\mathrm{Fs}}
$$

Although Eqs. (1) and (2) are derived independently, they correspond to a common internal reaction:

$$
\mathrm{Fe}^{\mathrm{M} 1}+\mathrm{Mg}^{\mathrm{M} 2} \rightleftharpoons \mathrm{Mg}^{\mathrm{M} 1}+\mathrm{Fe}^{\mathrm{M} 2}
$$

Approximating that cations in each site are distributed at random, we can write the molefraction of the molecules as

$$
\begin{array}{ll}
\mathrm{X}_{\mathrm{En}}=\mathrm{X}_{\mathrm{Mg}}^{\mathrm{M} 1} \mathrm{X}_{\mathrm{Mg}}^{\mathrm{M} 2}, & \mathrm{X}_{\mathrm{Fs}}=\mathrm{X}_{\mathrm{Fe}}^{\mathrm{M} 1} \mathrm{X}_{\mathrm{Fe}}^{\mathrm{M} 2}, \\
\mathrm{X}_{\mathrm{A}}=\mathrm{X}_{\mathrm{Fe}}^{\mathrm{M} 1} \mathrm{X}_{\mathrm{Mg}}^{\mathrm{M} 2}, & \mathrm{X}_{\mathrm{B}}=\mathrm{X}_{\mathrm{Mg}}^{\mathrm{M} 1} \mathrm{X}_{\mathrm{Fe}}^{\mathrm{M} 2}
\end{array}
$$

where $\mathrm{X}_{\mathrm{Mg}}^{\mathrm{M} 1}$ etc. are mole-fraction of the cations in each site. In the present system, we have:

$$
\mathrm{X}_{\mathrm{Mg}}^{\mathrm{M} 1}+\mathrm{X}_{\mathrm{Fe}}^{\mathrm{M} 1}=1, \quad \mathrm{X}_{\mathrm{Mg}}^{\mathrm{M} 2}+\mathrm{X}_{\mathrm{Fe}}^{\mathrm{M} 2}=1
$$

Then we can rewrite Eqs. (1) and (2) as

$$
\begin{gathered}
\mathrm{RT} \ln \mathrm{K}_{(1)}=-\Delta \mathrm{G}_{(1)}^{\circ}, \mathrm{K}_{(1)}=a_{\mathrm{A}} / a_{\mathrm{B}}, \\
\mathrm{K}_{(1)}=\mathrm{K}^{\prime} \cdot \gamma_{\mathrm{A}} / \gamma_{\mathrm{B}} \\
\mathrm{RT} \ln \mathrm{K}_{(2)}=-\Delta \mathrm{G}_{(2)}^{\circ} \quad \mathrm{K}_{(2)}=a_{\mathrm{A}}^{2} / a_{\mathrm{En}} \cdot a_{\mathrm{Fs}}, \\
\mathrm{K}_{(2)}=\mathrm{K}^{\prime} \cdot \gamma_{\mathrm{A}}^{2} / \gamma_{\mathrm{En}} \cdot \gamma_{\mathrm{Fs}} \\
\mathrm{K}^{\prime}=\frac{\mathrm{X}_{\mathrm{Fe}}^{\mathrm{M} 1} \mathrm{X}_{\mathrm{Mg}}^{\mathrm{M} 2}}{\mathrm{X}_{\mathrm{Mg}}^{\mathrm{M} 1} \mathrm{X}_{\mathrm{Fe}}^{\mathrm{M} 2}}
\end{gathered}
$$

where $K_{(1)}$ and $K_{(2)}$ are equilibrium constants, $a_{i}$ is activity, $\gamma_{i}$ is activity coefficient, and $K^{\prime}$ is apparent internal partition constant. The activity coefficient is given by definition

$$
\mathrm{RT} \ln \gamma_{\mathrm{K}}=\frac{\partial \mathrm{G}_{\mathrm{ex}}}{\partial \mathrm{n}_{\mathrm{K}}}
$$

where $G_{e x}$ is excess free energy in reference to the ideal site-preference model.

Since the molecules are considered to be distributed at random, $\mathrm{G}_{\mathrm{ex}}$ may be represented by the regular solution model as

$$
\begin{aligned}
\mathrm{G}_{\mathrm{ex}}= & n \overline{\mathrm{G}}_{\mathrm{ex}}, \mathrm{n}=\mathrm{n}_{\mathrm{En}}+\mathrm{n}_{\mathrm{Fs}}+\mathrm{n}_{\mathrm{A}}+\mathrm{n}_{\mathrm{B}} \\
\overline{\mathrm{G}}_{\mathrm{ex}}= & \alpha_{\mathrm{En} \cdot \mathrm{Fs}} \mathrm{X}_{\mathrm{En}} \mathrm{X}_{\mathrm{Fs}}+\alpha_{\mathrm{En} \cdot \mathrm{A}} \mathrm{X}_{\mathrm{En}} \mathrm{X}_{\mathrm{A}} \\
& +\alpha_{\mathrm{En} \cdot \mathrm{B}} \mathrm{X}_{\mathrm{En}} \mathrm{X}_{\mathrm{B}}+\alpha_{\mathrm{Fs} \cdot \mathrm{A}} \mathrm{X}_{\mathrm{Fs}} \mathrm{X}_{\mathrm{A}} \\
& +\alpha_{\mathrm{Fs} \cdot \mathrm{B}} \mathrm{X}_{\mathrm{Fs}} \mathrm{X}_{\mathrm{B}}+\alpha_{\mathrm{A} \cdot \mathrm{B}} \mathrm{X}_{\mathrm{A}} \mathrm{X}_{\mathrm{B}}
\end{aligned}
$$

where $\bar{G}_{\text {ex }}$ is the molar excess free energy in reference to the ideal site-preference model and $\alpha_{\text {En }}$.Fs etc. are non-ideal parameters. $\alpha_{\text {En.Fs }}$ etc. involve several kinds of cation interactions in general. The term $\mathrm{X}_{\mathrm{En}} \mathrm{X}_{\mathrm{Fs}}$ etc. correspond to the probability of the molecule pairs formed in the crystal. From Eq. (3), we have:

$$
\mathrm{X}_{\mathrm{En}} \mathrm{X}_{\mathrm{Fs}}=\mathrm{X}_{\mathrm{A}} \mathrm{X}_{\mathrm{B}}
$$

This is due to the fact that, as shown in Fig. 1, 
En-Fs and A-B pairs are identical except for the orientation of the molecules. As a result, statistically the same number of En-Fs and A-B pairs are expected in a unit quantity of the crystal. Using the relations $\mathrm{nX}_{\mathrm{En}} \mathrm{X}_{\mathrm{Fs}}=$ $\mathrm{n}_{\mathrm{En}} \mathrm{n}_{\mathrm{Fs}} / \mathrm{n}$ etc. and Eqs. (7), (8) and (9), we obtain the activity coefficient as given by OKA and Matsumoto (1974):

$$
R T \ln \gamma_{K}=\sum_{i} \alpha_{K \cdot i} X_{i}-\sum_{i} \sum_{j} \alpha_{i \cdot j} X_{i} X_{j}
$$

In this derivation, it is noted that $\mathrm{n}$ in Eq. (8) is not fixed and each $n_{K}$ in Eq. (7) is independent of each other. Therefore Eq. (10) is not valid in Eq. (7).

Using Eq. (11), we can write Eqs. (5) and (6) as

$$
\begin{aligned}
\mathrm{RT} \ln \mathrm{K}^{\prime}= & -\Delta \mathrm{G}_{(1)}^{\circ}+\alpha_{\mathrm{A} \cdot \mathrm{B}}\left(\mathrm{X}_{\mathrm{A}}-\mathrm{X}_{\mathrm{B}}\right) \\
& +\left(\alpha_{\mathrm{En} \cdot \mathrm{B}}-\alpha_{\mathrm{En} \cdot \mathrm{A}}\right) \mathrm{X}_{\mathrm{En}} \\
& +\left(\alpha_{\mathrm{Fs} \cdot \mathrm{B}}-\alpha_{\mathrm{Fs} \cdot \mathrm{A}}\right) \mathrm{X}_{\mathrm{Fs}}
\end{aligned}
$$

$$
\begin{aligned}
\mathrm{RT} \ln \mathrm{K}^{\prime}= & -\Delta \mathrm{G}_{(2)}^{\circ}+\left(\alpha_{\mathrm{Fs} \cdot \mathrm{A}}+\alpha_{\mathrm{En} \cdot \mathrm{A}}\right) \mathrm{X}_{\mathrm{A}} \\
& -\left(2 \alpha_{\mathrm{A} \cdot \mathrm{B}}-\alpha_{\mathrm{Fs} \cdot \mathrm{B}}-\alpha_{\mathrm{En} \cdot \mathrm{B}}\right) \mathrm{X}_{\mathrm{B}} \\
& +\left(\alpha_{\mathrm{En} \cdot \mathrm{Fs}}-2 \alpha_{\mathrm{En} \cdot \mathrm{A}}\right) \mathrm{X}_{\mathrm{En}} \\
& +\left(\alpha_{\mathrm{En} \cdot \mathrm{Fs}}-2 \alpha_{\mathrm{Fs} \cdot \mathrm{A}}\right) \mathrm{X}_{\mathrm{Fs}}
\end{aligned}
$$

Since Eqs. (1) and (2) correspond to a common reaction, Eqs. (12) and (13) are identical to each other. Then by comparing the terms in Eqs. (12) and (13), and using (3) and (4), we get the following relations for the thermodynamic parameters.

$$
\begin{aligned}
& \alpha_{\mathrm{Fs} \cdot \mathrm{B}}=\alpha_{\mathrm{En} \cdot \mathrm{A}}=\mathrm{W}^{\mathrm{M} 1}, \alpha_{\mathrm{En} \cdot \mathrm{B}}=\alpha_{\mathrm{Fs} \cdot \mathrm{A}}=\mathrm{W}^{\mathrm{M} 2}, \\
& \alpha_{\mathrm{A} \cdot \mathrm{B}}=\mathrm{W}^{\mathrm{M} 1}+\mathrm{W}^{\mathrm{M} 2}-\mathrm{W}^{\mathrm{M} 12} \\
& \alpha_{\mathrm{En} \cdot \mathrm{Fs}}=\mathrm{W}^{\mathrm{M} 1}+\mathrm{W}^{\mathrm{M} 2}+\mathrm{W}^{\mathrm{M} 12} \\
& \mathrm{~W}^{\mathrm{M} 12}=-\mu_{\mathrm{En}}^{\circ}-\mu_{\mathrm{Fs}}^{\circ}+\mu_{\mathrm{A}}^{\circ}+\mu_{\mathrm{B}}^{\circ}
\end{aligned}
$$

where $\mathrm{W}^{\mathrm{M} 1}, \mathrm{~W}^{\mathrm{M} 2}$ and $\mathrm{W}^{\mathrm{M} 12}$ are interaction parameters of $\mathrm{Fe}$ and $\mathrm{Mg}$ of $\mathrm{M} 1-\mathrm{M} 1, \mathrm{M} 2-\mathrm{M} 2$ and M1-M2 pairs, respectively. $\mu_{\mathrm{En}}^{\circ}$ etc. are chemical potential of the pure substance*. It is noted that $\alpha_{\mathrm{En} \cdot \mathrm{Fs}} \neq \alpha_{\mathrm{A} \cdot \mathrm{B}}$. This indicates that though the pairs $A-B$ and En-Fs are energetically equivalent, the excess free energy is different in the pair formation of $2 \mathrm{~A}-\mathrm{B} \leftrightarrow \mathrm{A}-\mathrm{A}+\mathrm{B}-\mathrm{B}$ and $2 \mathrm{En}-\mathrm{Fs} \leftrightarrow \mathrm{En}-\mathrm{En}+\mathrm{Fs}-\mathrm{Fs}$.

Using Eqs. (14), we can write Eqs. (12) and (13) as

$$
\begin{aligned}
\mathrm{RT} \ln \mathrm{K}^{\prime}= & -\Delta \mathrm{G}^{\circ}+\mathrm{W}^{\mathrm{M} 1}\left(2 \mathrm{X}_{\mathrm{Fe}}^{\mathrm{M} 1}-1\right) \\
& -\mathrm{W}^{\mathrm{M} 2}\left(2 \mathrm{X}_{\mathrm{Fe}}^{\mathrm{M} 2}-1\right)-\mathrm{W}^{\mathrm{M} 12}\left(\mathrm{X}_{\mathrm{Fe}}^{\mathrm{M} 1}\right. \\
& \left.-\mathrm{X}_{\mathrm{Fe}}^{\mathrm{M} 2}\right)
\end{aligned}
$$

where $\Delta G^{\circ}=\Delta G_{(1)}^{\circ}$.

$\overline{\mathrm{G}}_{\text {ex }}$ can be represented by using $\mathrm{W}^{\mathrm{M} 1}, \mathrm{~W}^{\mathrm{M} 2}$ and $\mathrm{W}^{\mathrm{M} 12}$ as

$$
\begin{aligned}
\bar{G}_{e x}= & \left(W^{M 1}+W^{M 2}+W^{M 12}\right) X_{E n} X_{F s} \\
& +W^{M 1} X_{E n} X_{A}+W^{M 2} X_{E n} X_{B} \\
& +W^{M 1} X_{F s} X_{B}+W^{M 2} X_{F s} X_{A} \\
& +\left(W^{M 1}+W^{M 2}-W^{M 12}\right) X_{A} X_{B}
\end{aligned}
$$

Since $\mathrm{X}_{\mathrm{En}} \mathrm{X}_{\mathrm{Fs}}=\mathrm{X}_{\mathrm{A}} \mathrm{X}_{\mathrm{B}}, \mathrm{W}^{\mathrm{M} 12}$ does not appear explicitly in $\overline{\mathrm{G}}_{\mathrm{ex}}$. However, the same care as mentioned before should be given also in the derivation of activity coefficient.

\section{Discussion}

Eq. (15) is the complete form of the equation proposed by SAXENA and GHOSE (1971). Unfortunately, the thermodynamic parameters can not be determined uniquely by site-occupancy measurements. This is due to the fact that $\alpha_{\mathrm{En} \cdot \mathrm{Fs}} \neq \alpha_{\mathrm{A} \cdot \mathrm{B}}$, while A-B and En-Fs pairs are indistinguishable from the site occupancy data. Eq. (15) can be rewritten as

$$
\mathrm{RT} \ln \mathrm{K}^{\prime}=-\Delta \mathrm{G}^{\circ}+\left(\mathrm{W}^{\mathrm{M} 1}-\mathrm{W}^{\mathrm{M} 2}\right)\left(2 \overline{\mathrm{X}}_{\mathrm{Fe}}-1\right)
$$




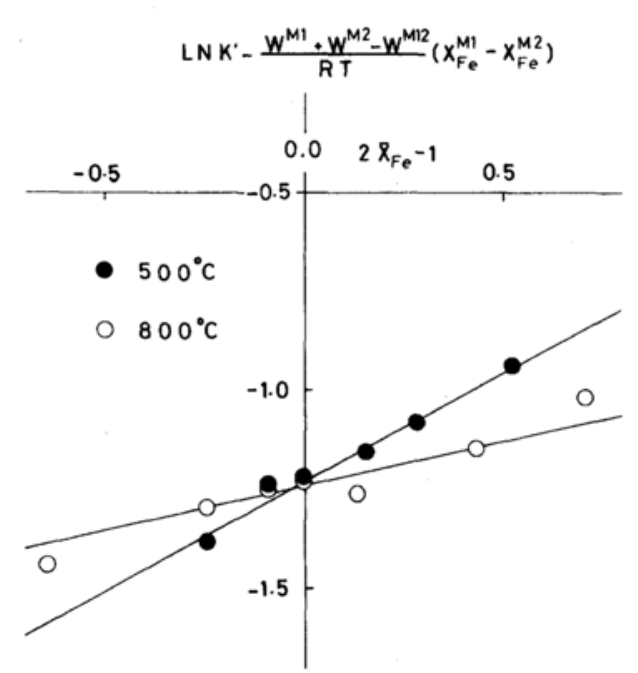

Fig. 2 (a)

Fig. 2 (a) and (b). Examples of the fit of the experiments by SAXENA and GHOSE (1971) according to Eq. (16).

$$
+\left(\mathrm{W}^{\mathrm{M} 1}+\mathrm{W}^{\mathrm{M} 2}-\mathrm{W}^{\mathrm{M} 12}\right)\left(\mathrm{X}_{\mathrm{Fe}}^{\mathrm{M} 1}-\mathrm{X}_{\mathrm{Fe}}^{\mathrm{M} 2}\right)
$$

where $2 \overline{\mathrm{X}}_{\mathrm{Fe}}=\mathrm{X}_{\mathrm{Fe}}^{\mathrm{M} 1}+\mathrm{X}_{\mathrm{Fe}}^{\mathrm{M} 2}$

In order to examine this solution model, the data of the site-occupancy measurements by SAXENA and GHOSE (1971) are plotted in Fig. 2(a) and (b) according to Eq. (16). The thermodynamic parameters determined by Eq. (16) are listed in Table 1. The linearity expected from Eq. (16) is excellent. The reason for the success of the equation proposed by SAXENA and GHose (1971) is obviously due to the fact that Eq. (16) and their equation (Eq. (3) in SAXENA and GHOSE, 1971) have the same mathematical forms, except for the meaning of the thermodynamic parameters. It is interesting to formulate the non-ideal behaviour of orthopyroxene in equilibrium with other minerals.

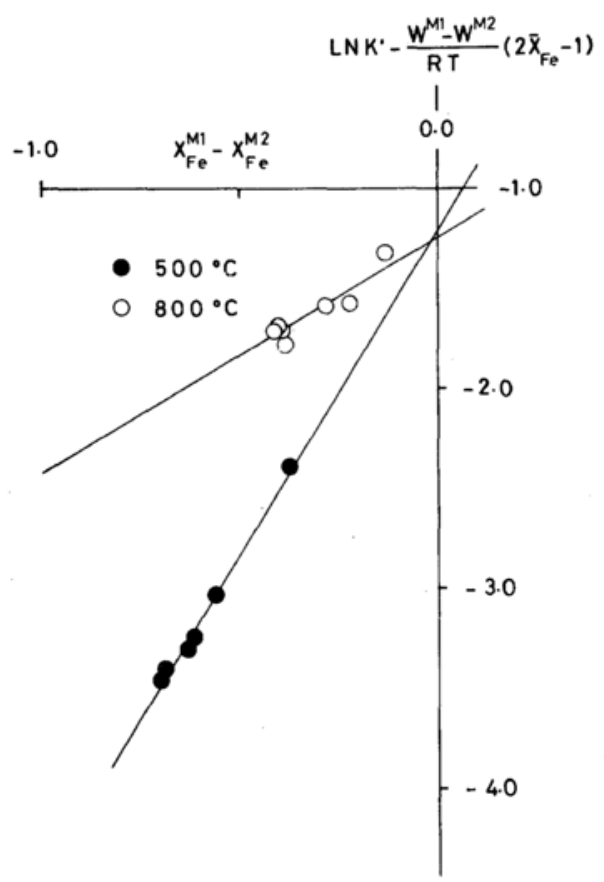

Fig. 2 (b)

For an exchange reaction of $\mathrm{Fe}$ and $\mathrm{Mg}$ between orthopyroxene and other coexisting minerals, it is convenient to treat the quantity RTln $\left(\mathrm{a}_{\mathrm{Fs}} / \mathrm{a}_{\mathrm{En}}\right)$. According to the present solution model we have:

$$
\begin{aligned}
\mathrm{RT} \ln \frac{a_{\mathrm{Fs}}}{a_{\mathrm{En}}}= & \mathrm{RT} \ln \frac{\mathrm{X}_{\mathrm{Fe}}^{\mathrm{M} 1} \mathrm{X}_{\mathrm{Fe}}^{\mathrm{M} 2}}{\mathrm{X}_{\mathrm{Mg}}^{\mathrm{M} 1} \mathrm{X}_{\mathrm{Mg}}^{\mathrm{M} 2}}+\left(\mathrm{W}^{\mathrm{M} 1}+\mathrm{W}^{\mathrm{M} 2}\right. \\
& \left.+\mathrm{W}^{\mathrm{M} 12}\right)\left(1-2 \overline{\mathrm{X}}_{\mathrm{Fe}}\right)-\left(\mathrm{W}^{\mathrm{M} 1}\right. \\
& \left.-\mathrm{W}^{\mathrm{M} 2}\right)\left(\mathrm{X}_{\mathrm{Fe}}^{\mathrm{M} 1}-\mathrm{X}_{\mathrm{Fe}}^{\mathrm{M} 2}\right)
\end{aligned}
$$

Again, we can not determine the thermodynamic parameters in this equation from the site-occupancy measurements only.

At high temperatures, the third term in Eq. (17)

Table 1. Calculated thermodynamic parameters in Eq. (16). The standard errors are shown in parentheses.

\begin{tabular}{cccc}
\hline \hline $\mathrm{T}\left({ }^{\circ} \mathrm{C}\right)$ & $\begin{array}{c}\Delta \mathrm{G}^{\circ} \\
(\mathrm{kcal})\end{array}$ & $\begin{array}{c}\mathrm{W}^{\mathrm{M} 1}+\mathrm{W}^{\mathrm{M} 2}-\mathrm{W}^{\mathrm{M} 12} \\
(\mathrm{kcal})\end{array}$ & $\begin{array}{c}\mathrm{W}^{\mathrm{M} 1}-\mathrm{W}^{\mathrm{M} 2} \\
(\mathrm{kcal})\end{array}$ \\
\hline $\mathbf{8 0 0}$ & $2.64(0.31)$ & $2.67(0.81)$ & $0.42(0.19)$ \\
700 & $2.53(0.30)$ & $3.05(0.68)$ & $0.59(0.18)$ \\
600 & $1.84(0.32)$ & $4.58(0.60)$ & $0.11(0.22)$ \\
500 & $1.86(0.20)$ & $4.97(0.31)$ & $0.91(0.17)$ \\
\hline
\end{tabular}




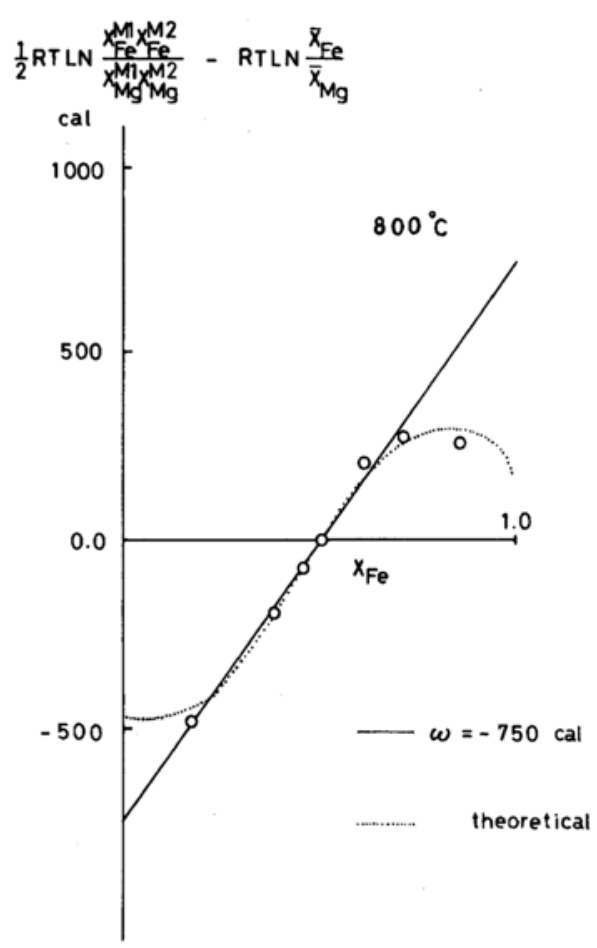

Fig. 3. Deviation of the term $R T \ln \left(\bar{X}_{\mathrm{Fe}} / \bar{X}_{\mathrm{Mg}}\right)$ from $1 / 2 R T \ln \left(X_{\mathrm{Fe}}^{\mathrm{M1}} X_{\mathrm{Fe}}^{\mathrm{M} 2} / X_{\mathrm{Mg}}^{\mathrm{Ml}} X_{\mathrm{Mg}}^{\mathrm{M} 2}\right)$ at $800^{\circ} \mathrm{C}$. The source data are given in SAXENA and GHOSE (1971). The deviation can be approximated by Eq. (18) with $\omega=$ $-700 \sim-800 \mathrm{cal}$, except for Fe-rich side and extremely Mg-rich side. The theoretical curve is calculated numerically on the basis of Eq. (16) with the parameters in Table 1.

is negligible and $\mathrm{RT} \ln \left(\mathrm{X}_{\mathrm{Fe}}^{\mathrm{M} 1} \mathrm{X}_{\mathrm{Fe}}^{\mathrm{M} 2} / \mathrm{X}_{\mathrm{Mg}}^{\mathrm{M} 1} \mathrm{X}_{\mathrm{Mg}}^{\mathrm{M} 2}\right)$ can be approximated as (Fig. 3)

$$
\begin{aligned}
& R T \ln \frac{\mathrm{X}_{\mathrm{Fe}}^{\mathrm{M} 1} \mathrm{X}_{\mathrm{Fe}}^{\mathrm{M} 2}}{\mathrm{X}_{\mathrm{Mg}}^{\mathrm{M} 1} \mathrm{X}_{\mathrm{Mg}}^{\mathrm{M} 2}} \cong \mathrm{RT} \ln \frac{\overline{\mathrm{X}}_{\mathrm{Fe}}}{\overline{\mathrm{X}}_{\mathrm{Mg}}} \\
&+\omega\left(1-2 \overline{\mathrm{X}}_{\mathrm{Fe}}\right)
\end{aligned}
$$

where $2 \bar{X}_{\mathrm{Mg}}=\mathrm{X}_{\mathrm{Mg}}^{\mathrm{M} 1}+\mathrm{X}_{\mathrm{Mg}}^{\mathrm{M} 2} . \quad \omega \cong-750 \mathrm{cal}$ at $800^{\circ} \mathrm{C}$.

Then Eq. (17) can be written in a form of the simple solution (THOMPSON, 1967) as

$$
\frac{1}{2} \mathrm{RT} \ln \frac{a_{\mathrm{Fs}}}{a_{\mathrm{En}}}=\mathrm{RT} \ln \frac{\overline{\mathrm{X}}_{\mathrm{Fs}}}{\overline{\mathrm{X}}_{\mathrm{Mg}}}+\alpha\left(1-2 \overline{\mathrm{X}}_{\mathrm{Fe}}\right)
$$

where $\bar{\alpha}=\frac{1}{2}\left(\mathrm{~W}^{\mathrm{M} 1}+\mathrm{W}^{\mathrm{M} 2}+\mathrm{W}^{\mathrm{M} 12}\right)+\omega$

$\bar{\alpha}$ can be determined from the partition experiments of $\mathrm{Fe}$ and $\mathrm{Mg}$ between coexisting orthopyroxene and olivine (NAFTZIGER and Muan, 1967; Larimer, 1968; Medaris, 1969; Matsui and Nishizawa, 1974). Then using Eqs. (16) and (19), $\mathrm{W}^{\mathrm{M} 1}, \mathrm{~W}^{\mathrm{M} 2}$ and $\mathrm{W}^{\mathrm{M} 12}$ can be determined simultaneously. However, $\bar{\alpha}$ obtained from these experiments has considerable uncertainty (MATSUI and NishizAWA, 1974) and no definite conclusion is given for the magnitude of $\mathrm{W}^{\mathrm{M} 1}, \mathrm{~W}^{\mathrm{M} 2}$ and $\mathrm{W}^{\mathrm{M} 12}$ at present.

Acknowledgements-I sincerely thank Dr. SHOHEI BANNO of Kanazawa University and Dr. YosHITO MATSUI of Okayama University for invaluable comments and discussions. I am also grateful to Prof. Kenzo Yagi, Drs. Kosuke ONUMA and AloK K. GUPTA of Hokkaido University, Mr. ISAO SUZUKI of Okayama University and Mr. HIDEO YABUKI of The Institute of Physical and Chemical Research for critical reading the manuscript. Computations were carried out at The Hokkaido University Computing Centre.

\section{REFERENCES}

BANNO, S. (1974) Element distributions in metamorphic petrology. In: Symposium on experimental petrology. Japan Assoc. Mineral. Petrol. Econ. Geol. (in Japanese).

BANNO, S. and MATSUI, Y. (1967) Thermodynamic properties of intra-crystalline exchange solid solution. Proc. Japan Acad. 43, 762-767.

LARIMER, J. W. (1968) Experimental studies on the system $\mathrm{Fe}-\mathrm{MgO}-\mathrm{SiO}_{2}-\mathrm{O}_{2}$ and their bearing on the petrology of chondritic meteorites. Geochim. Cosmochim. Acta 32, 1187-1207.

MATSUI, Y. and NishiZAWA, O. (1975) Iron(II)magnesium exchange equilibrium between olivine and calcium-free pyroxene over a temperature range $800^{\circ} \mathrm{C}$ to $1,300^{\circ} \mathrm{C}$. Bull. Soc. fr. Mineral. Crystl. 97, 122-130.

MEDaris, L. G. (1969) Partitioning of $\mathrm{Fe}^{++}$and $\mathrm{Mg}^{++}$ between coexisting synthetic olivine and orthopyroxene. Am. J. Sci. 267, 945-968.

Mueller, R. F., GHOSE, S. and SAXENA, S. K. (1970) Partitioning of cations between coexisting singleand multi-site phases. A discussion. Geochim. Cosmochim. Acta 34, 1356-1360.

NAFTZIGER, R. H. and MUAN, A. (1967) Equilibrium phase compositions and thermodynamic properties of olivines and pyroxenes in the system $\mathrm{MgO}$-"FeO"$\mathrm{SiO}_{2}$. Am. Mineral. 52, 1364-1385.

OKA, Y. and MATSUMOTO, T. (1974) Study on the 
compositional dependence of the apparent partition coefficient of iron and magnesium between coexisting garnet and clinopyroxene solid solution. Contrib. Mineral. Petrol. 48, 115-121.

SAXENA, S. K. (1973) Thermodynamics of rock-forming crystalline solutions. Springer-Verlag.

SAXENA, S. K. and GHOSE, S. (1971) $\mathrm{Mg}^{2+}-\mathrm{Fe}^{2+}$ order- disorder and the thermodynamics of the orthopyroxene crystalline solution. Am. Mineral. 56, 532-559.

THOMPSON, J. B. (1967) Thermodynamic properties of simple solutions. In Researches in geochemistry 2, (ed. P. H. ABELSON) 340-361. John Willey and Sons. 